\title{
Physicochemical characterization of bunches and oil composition in a backcross progeny (caiaué $x$ oil palm) $x$ oil palm
}

\author{
Ricardo Lopes ${ }^{1}$, Rosemar Antoniassi ${ }^{1}$, Raimundo Nonato Vieira Cunha ${ }^{2}$, Allan Eduardo Wilhelm ${ }^{2}$, Adelia \\ Ferreira Faria-Machado ${ }^{2}$ \\ ${ }^{1}$ Embrapa Amazônia Ocidental, Manaus, AM. ${ }^{1}$ Embrapa Agroindústria de Alimentos, Rio de Janeiro, RJ. E-mail: \\ ricardo.lopes@embrapa.br
}

\begin{abstract}
Hybrids between caiaue and oil palm (IEH OxG) are explored in genetic improvement with the main objective of associating the high palm oil productivity of oil palm with resistance of caiaue to Bud Rot disease. In addition, caiaué has better oil quality and greater resistance to some pests and diseases than oil palm and these characteristics are transmitted to the hybrid between species. Due to fertility problems, IEH OxG plantations require assisted pollination, which raises the production costs. Backcrossings using oil palm as recurrent parent $(B C O G \times G)$ are being evaluated as a solution to restore the fertility of IEH OxG, however, the species contrast to physicochemical characteristics of the bunch and to oil composition, therefore, there is a need to observe how these characteristics vary in BC OGXG. Physicochemical characteristics of the bunch and fatty acid composition of the oil produced by 90 plants from an BC OGXG progeny were analysed. A large variation was observed in the progeny, with mean values of $9.0 \mathrm{~kg}$ for bunch weight, $46.0 \%$ of parthenocarpic fruits in the bunch weight, $72.2 \%$ of mesocarp in normal fruit and $86.5 \%$ in parthenocarpic fruit, $37.6 \%$ of oil in the humid mesocarp of normal fruits and $35.9 \%$ in parthenocarpic fruits and $16.4 \%$ of oil content in the fresh fruits bunch (FFB). The unsaturated fatty acids oleic (52.5\%) and linoleic (10.8\%) and the saturated fatty acids palmitic (30.7\%) and stearic (4.4\%) stood out in the oil composition. In the progeny $B C$ OGXG is possible to select individuals for high $O C B$ and for a greater or lesser percentage of saturated or unsaturated fatty acids in the oil composition.
\end{abstract}

Keywords: fatty acids; interspecific cross; Elaeis guineensis; Elaeis oleifera.

Caracterização físico-química dos cachos e composição do óleo em progênie do retrocruzamento (caiaué $x$ dendezeiro) $x$ dendezeiro

\section{Resumo}

Híbridos interespecíficos de caiaué com dendezeiro (HIE OxG) são explorados no melhoramento genético com objetivo principal de associar a alta produtividade em óleo de palma do dendezeiro com a resistência do caiaué a anomalia Amarelecimento Fatal. Além disso, o caiaué apresenta também melhor qualidade de óleo e maior resistência a algumas pragas e doenças do que a palma de óleo e que são transmitidas para o híbrido entre as espécies. Devido a problemas de fertilidade, os plantios do HIE OxG requerem polinização assistida, o que aumenta os custos de produção. Retrocruzamentos utilizando o dendezeiro como genitor recorrente (RC OGXG) estão sendo avaliados como solução para restaurar a fertilidade dos HIE OxG, contudo, as espécies contrastam para as características físico-químicas dos cachos e também na composição em ácidos graxos do óleo, sendo necessário verificar como essas características variam no RC OGXG. Foram avaliadas as características físico-químicas dos cachos e composição em ácidos graxos do óleo produzido por 90 plantas de uma progênie RC OGxG. Ampla variação foi observada na progênie, com valores médios de $9,0 \mathrm{~kg}$ para peso dos cachos, $46,0 \%$ de frutos partenocárpicos no peso dos cachos, $72,2 \%$ de mesocarpo no fruto normal e $86,5 \%$ no fruto partenocárpico, $37,6 \%$ de óleo no mesocarpo úmido de frutos normais e $35,9 \%$ nos frutos partenocárpicos e 16,4\% para percentual de óleo nos cachos de frutos frescos. Na composição do óleo destacaram-se os ácidos graxos insaturados oleico $(52,5 \%)$ e linoleico $(10,8 \%)$ e os saturados palmítico $(30,7 \%)$ e esteárico $(4,4 \%)$. Na progênie RC OGxG é possível selecionar 
indivíduos para alto percentual de óleo no cacho e para maior ou menor percentual de ácidos graxos saturados ou insaturados na composição do óleo.

Palavras-chave: ácidos graxos; cruzamento interespecífico; Elaeis guineensis Jacq.; Elaeis oleifera (Kunth) Cortés.

\section{Introduction}

The oil palm (Elaeis guineensis Jacq.) accounts for the majority of the vegetable oil produced in the world, $40.21 \%$ in total, of which $36.03 \%$ is palm oil, extracted from the fruit mesocarp, and $4.18 \%$ of palm kernel oil, extracted from the endosperm of the fruit (USDA, 2021). Of the same genus as palm oil, caiaué (E. oleifera HBK Cortes), a palm tree native to the American continent, produces an oil similar to palm oil in the mesocarp of its fruit, but with important differences, such as a higher concentration of antioxidants, low lipase enzyme activity and higher proportion of unsaturated fatty acids (CADENA et al., 2012; LIEB et al., 2017, CHAVES et al., 2018). On the other hand, caiaué fruits have a lower proportion of mesocarp in the fruit and oil in the mesocarp than oil palm fruits (LIEB et al., 2017), which partly explains their lower potential for exploitation in commercial production of oil.

The hybridization between caiaué and oil palm is explored in genetic improvement particularly for introducing in oil palm the resistance to the disease named Bud Rot (BR), shown by caiaue (BARBA, 2016). The interspecific hybrid between caiaue and palm (IEH $O \times G$ ) is resistant to Bud Rot disease and the interspecific hybrid cultivars are the only option for palm cultivation in areas where the disease has occurred. Nevertheless, the fertility of these hybrids is partial, therefore, it is necessary to perform assisted pollination so that the plants express their productive potential (SOCHA et al., 2019). Assisted pollination is an expensive activity. It requires the collection of pollen and its processing and 2 to 3 -day pollination shifts, increasing the demand for field and supervisory labor, reducing the profitability of IEH OxG cultivation. The most promising solution for restoring the fertility of IEH OXG and maintaining the resistance to $B R$ is through backcrossing using oil palm as recurrent parent (BARBA, 2016).

The palm oil produced by IEH OXG has characteristics intermediate to the oils of its parents, caiaué and oil palm (RIOS et al., 2015), therefore, a great segregation for oil composition in backcross progenies is expected. The palm oil produced by IEH OxG has a lower amount of free fatty acids than that produced by oil palm, so it is an oil with less acidity and better quality, it is also more unsaturated and with a higher content of vitamin E and carotenes (CADENA et al., 2012; MOZZON et al., 2018; CHAVES et al., 2018; ANTONIASSI et al., 2018). Studies show that IEH OxG oil has the potential to prepare functional foods with antioxidant properties and a favorable impact on human plasma lipids, related to cardiovascular risk factors (LUCCl et al., 2016; RODRIGUEZ et al., 2016). Because the interest in the fractions or components of palm oil depends on the purpose of the use, one can, for example, have a greater interest in the olein, which is found in greater proportion in the palm oil of caiaue and IEH OxG, or in the stearin, in this case, found in greater proportion in palm oil produced by oil palm. As the fatty acid composition of palm oil produced by IEH OxG is different from that produced by oil palm, a specific identity pattern for this oil was proposed in Codex Alimentarus, in which the palm oil with higher oleic acid was recognized, which should have a percentage equal to a greater than $48 \%$ oleic acid in its composition (FAO, 2017).

Considering the importance of the composition of palm oil for the market and the variation found between caiaué and oil palm species, it is essential for breeding programs that explore interspecific hybridization to know the production, and composition of oil in these progenies. In this context, the objective of this study was to evaluate the physicochemical characterization of bunches and composition palm oil produced by plants from a backcross progeny (caiaué $\mathrm{x}$ oil palm) $\mathrm{x}$ oil palm.

\section{Material and Methods}

The progeny was planted in June 1993, at the Rio Urubu Experimental Field (CERU), owned 
by Embrapa Amazônia Ocidental, located in the municipality of Rio Preto da Eva, Amazonas, latitude $2^{\circ} 25^{\prime} \mathrm{S}$, longitude $59^{\circ} 33^{\prime} \mathrm{W}$. The climate in CERU is of the Ami type (Köppen's classification), hot and humid, temperature with average values of $31.2{ }^{\circ} \mathrm{C}$ and $23.5{ }^{\circ} \mathrm{C}$ for maximum and minimum, respectively, and rainfall around 2,200 $\mathrm{mm} /$ year, air relative humidity pressure of around $85 \%$, average annual total sunshine of 1,940 hours and on a Yellow Latosol-type soil with a very clayey texture. The physicochemical characterization of the bunches and the composition of palm oil in fatty acids were evaluated in a progeny with 90 individuals of an interspecific backcross (caiaué $\mathrm{x}$ oil palm) $\mathrm{x}$ oil palm. The progeny was obtained by crossing using as a female parent a hybrid plant (ISH OxG) from the interspecific crossing between caiaué (parent CA 09 D originated from Caldeirão) with oil palm (parent $138 \mathrm{~T}$, commercial material originating from IRHO) and as a male parent an oil palm plant (Genitor PO 2558 P, originated from IRHO). This genetic configuration represents the first generation of interspecific backcrossing (BC OGXG) between the species caiaué and oil palm, using oil palm as a recurrent parent.

The physicochemical analyses of the bunches were carried out in 2014 and 2015 at the Oil Palm and Agroenergy Laboratory of Embrapa Amazônia Ocidental. The optimal harvest time for both quantitative (i.e., extraction rate, industrial applications, etc.) and qualitative (i.e., nutritional properties) characteristics of the $\mathrm{O} \times \mathrm{G}$ interspecifics hybrids is 24 weeks after anthesis (LUCCl et al., 2015). However, this time is variable between climatic stations and environmental conditions, for this reason, the bunches maturation point for harvesting was established based on the field criterion used in oil palm commercial plantations, which consists of the presence at least one loose fruit per bunch (FREITAS et al., 2021). Two bunches were analyzed of each plant, one harvested in 2014 and the other in 2015. The methodology used to analysis bunches was adapted from the Nigerian Institute for Oil Palm Research (RAO et al., 1983). Ripe bunches harvested in the field were immediately taken to the laboratory for evaluation of the bunch weight (BW), rachis weight (RW), spikelets with fruits weight (WS), normal fruits (NF) and parthenocarpic fruits (PF) weight in the fresh fruit bunch (FFB). Two samples with 50 fruits, one of NF and another of $\mathrm{PF}$, were used to determine the percentage of mesocarp (M) in the weight of the fruit and percentage of diaspore (DIASP) in the weight of the fruit (Figure 1). To obtain the percentage of palm oil in the mesocarp of normal fruit (ONF) and parthenocarpic fruit (OPF) were used $40 \mathrm{~g}$ of fresh mesocarp from each fruit type. After drying at 105 o $\mathrm{C}$ in an oven for $24 \mathrm{~h}$ two samples with 5 $\mathrm{g}$ of dry mesocarp from each type of fruit were analyzed by bunch. The oil was extracted in a Soxhlet system, using petroleum ether $\left(30-60^{\circ} \mathrm{C}\right)$ as a solvent and an extraction-time of 16h (AOAC, 2005). The determination of the palm oil content in the FFB, expressed as a percentage of the weight of the bunches, was carried out as follows:

$$
\begin{aligned}
& \mathrm{POB}(\%)=\frac{O N F}{F F B}(\%)+\frac{O P F}{F F B}(\%)(1) \\
& \frac{O N F \text { or } O P F}{F F B}(\%)= \\
& \frac{1}{10,000}\left[\left(\frac{N F \text { or } P F}{F F B}(\%)\right)\left(\frac{M}{N F \text { or } P F}(\%)\right)\left(\frac{O}{M N F \text { or } M O F}(\%)\right)\right]
\end{aligned}
$$$$
\text { (2) }
$$$$
\begin{aligned}
& \frac{N F \text { or } P F}{F F B}(\%)= \\
& 100\left[\left(\frac{N F \text { or } P F}{\text { spiklets with fruits }}\right)\left(\frac{F F B-\text { Rachis }}{F F B}\right)\right] \text { (3) }
\end{aligned}
$$$$
\frac{M}{N F \text { or } P F}(\%)=100\left(\frac{(N F \text { or } P F)-\text { Diasspore }}{(N F \text { or } P F)}\right)(4)
$$$$
\begin{aligned}
& \frac{O}{M N F \text { or } M P F}(\%)= \\
& \frac{1}{100}[(100-
\end{aligned}
$$$$
\text { Mesocarp moisture NF or PF(\%)) } \left.\left(\frac{O}{M N F \text { or } M P F_{(D R Y)}}(\%)\right)\right]
$$

\section{Where:}

$\mathrm{POB}=$ Palm oil content in the fresh fruit bunch $F F B=$ fresh fruit bunch

ONF = palm oil in the mesocarp of normal fruit OPF = palm oil in the mesocarp of parthenocarpic fruit

$\mathrm{NF}=$ normal fruit

$\mathrm{PF}=$ parthenocarpic fruit

$\mathrm{M}=$ mesocarp

$\mathrm{O}=$ palm oil

MNF = mesocarp in the normal fruit

$\mathrm{MPF}=$ mesocarp in the parthenocarpic fruit 
Figure 1. Oil palm Bunches components (Photos: Alessandra Ferraiolo N. Domingues).

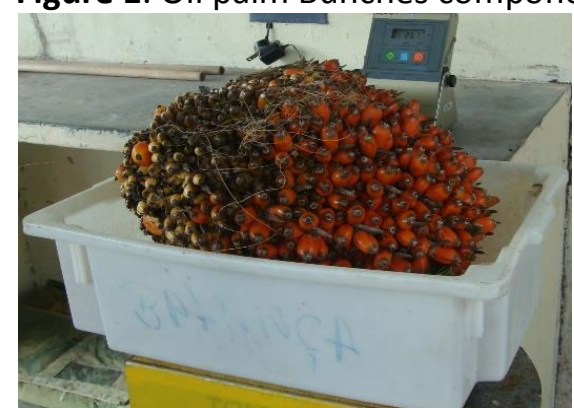

(a) Bunche

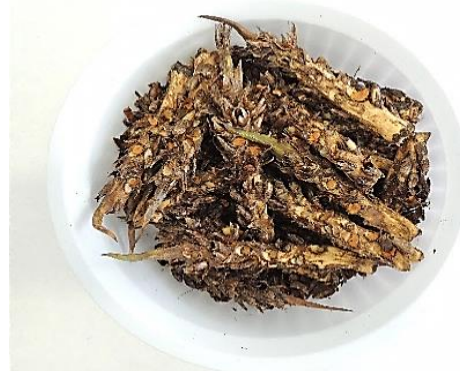

(d) Empty spikelets

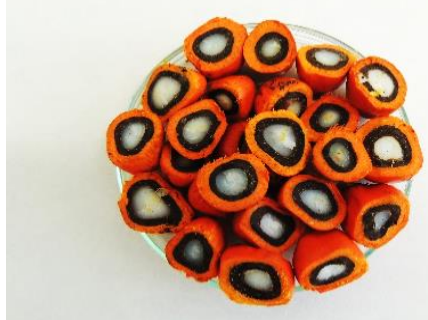

(g) Normal fruits with diaspore

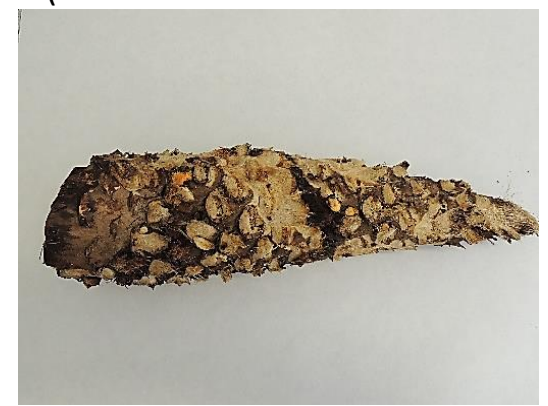

(b) Rachis

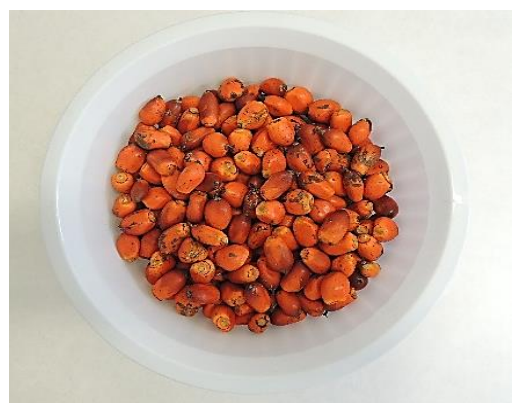

(e) Normal fruits

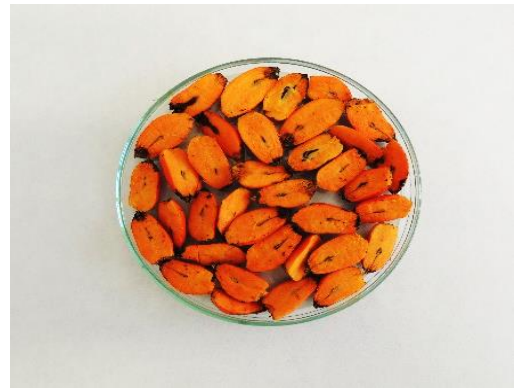

(h) Parthenocarpic fruits without diaspore

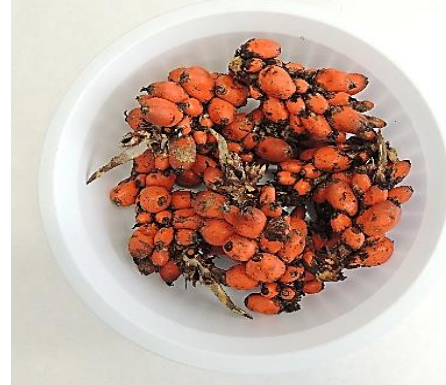

(c) Spikelets with normal and parthenocarpic fruits

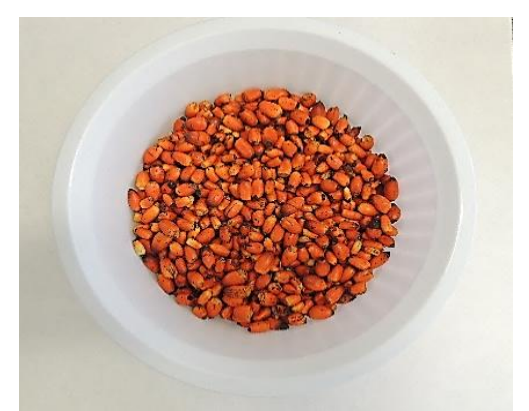

(f) Parthenocarpic fruits

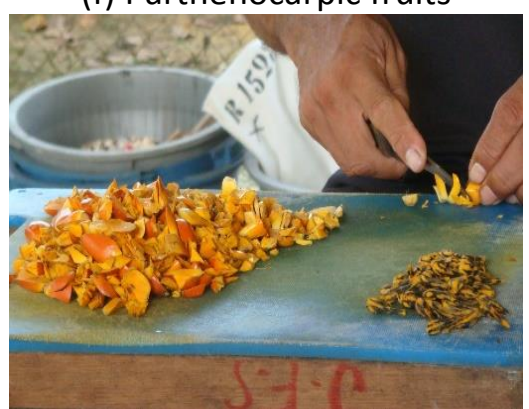

(i) Manual removal of the mesocarp from the fruit
The analysis of the composition of palm oil in fatty acids was carried out at the Oil and Fats Laboratory of Embrapa Agroindústria de Alimentos, Rio de Janeiro, Rio de Janeiro State. It was analyzed two samples per plant, obtained from the same bunches used in physicochemical analyses, with three replicates of each sample. The oil samples were obtained from the dry mesocarp of the fruits of the same bunches after extraction with petroleum ether in Soxhlet Extractor. The solvent was removed in a rotaryevaporator and under nitrogen flow. For analysis of the oil composition in fatty acids, the methyl esters were prepared according to the Hartman and Lago (1973) method and analyzed through chromatography in the gas phase on an Agilent 7890 gadget, equipped with a flame ionization detector operated at $280^{\circ} \mathrm{C}$.

A capillary column of fused silica of nitroterephthalic acid modified polyethylene glycol film - FFAP (25 m x $0.32 \mathrm{~mm} \times 0.25 \mu \mathrm{m})$ was used according to the following schedule: initial temperature of $150{ }^{\circ} \mathrm{C}$ for $1 \mathrm{~min}$; from 150 ${ }^{\circ} \mathrm{C}$ to $180^{\circ} \mathrm{C}$ with a ramp of $30^{\circ} \mathrm{C} / \mathrm{min}$; from 180 to $200^{\circ} \mathrm{C}$ with a ramp of $20^{\circ} \mathrm{C} / \mathrm{min}$; from 200 to $230^{\circ} \mathrm{C}$ with a ramp of $3{ }^{\circ} \mathrm{C} / \mathrm{min}$ and at the final temperature of $230^{\circ} \mathrm{C}$ for $10 \mathrm{~min} .1 \mu \mathrm{L}$ of sample was injected into an injector heated to $250{ }^{\circ} \mathrm{C}$ operated in the 1:50 flow division mode. Fatty acids were identified by comparing the retention times with the NU-CHEK Prep, Inc. (Elysian, MN) standards numbers 62, 79 and 87. The quantification was performed through internal normalization and the results were expressed as a percentage of the different fatty acids in the total fatty acids in the oil.

The data of the physicochemical composition of the bunches and the fatty acid composition of the palm oil of the progeny individuals were analyzed with descriptive 
statistics (mean, minimum value, maximum value, standard deviation and variation coefficient), frequency of classes and Pearson's correlation coefficient. The composition of the palm oil in fatty acids of the interspecific backcross progeny (BC OGxG) was compared with that produced by caiaué plant used with female parent to obtain the interspecific hybrid F1 (ISH OxG), female parent of the backcross progeny. The oil palm ancestors were not available, so they were not included in the study.

\section{Results and Discussion}

A wide variation was observed in the $B C$ OGXG progeny for weight and composition of the bunch, according to the descriptive statistics (Table 1) and mean distribution of the individuals (Figure 2), which is expected because it is an interspecific backcross, with great divergence between the parent specie for bunches physicochemical characteristics. The largest variations were observed for the percentage of palm oil from parthenocarpic fruits in FFB weight (OBPF), $\quad \mathrm{CV}=85.3 \%$, and percentage of parthenocarpic fruits in FFB weight (PFB), CV = $80.1 \%$, while the smallest variations were observed for percentage of oil in dry mesocarp of normal fruits (ODMFN), $\mathrm{CV}=11.7 \%$, and percentage of mesocarp in normal fruits weight (MNF), CV $=13.4 \%$. The other characteristics presented intermediate CV, between $23.0 \%$ (percentage of normal fruits in FFB weight - NFP) and $48.2 \%$ (percentage of diaspore in fruit weight - DIASP). The variable OBPF is derived from the components PFB, MPF and OMPF. That is why, the large variation observed in OBPF $(85.3 \%)$ can be attributed mainly for variation observed in PFB $(80.1 \%)$, since the variations in MPF $(23,7 \%)$ and OMPF (30.9\%) were smaller. In the oil palm fruiting process, normal and parthenocarpic fruits are formed. Under suitable pollination conditions, in oil palm normal fruits represent on average $58 \%$ of the bunch weight and parthenocarpic fruits 3\% (CORLEY; TINKER, 2016), while in caiaué they may constitute up to $90 \%$ of the total fruits
(NTSOMBOH-NTSEFONG et al., 2016). Parthenocarpy has genetic basis (defined before anthesis), which is more evident in caiaué, but is also influenced by pollination (defined after anthesis). In the same bunch the variation in the weight of parthenocarpic fruits is greater than that observed in normal fruits. Among the fruits classified as parthenocarpics sometimes occurs fruits with formation of endocarp, but without the formation of almond, which are classified as false parthenocarpic and these are heavier than the trues parthenocarpics. Due to these factors, in backcross progenies (OxG) $x G$ large variation is expected for the percentage of parthenocarp fruits on the bunche weight.

The mean value for FFB weight (BW) was $9.0 \mathrm{~kg}$, with a variation from $2.7 \mathrm{~kg}$ to $21.3 \mathrm{~kg}$. In the evaluation of five BC OGXG progenies, Bastidas et al. (2007) observed for BW a mean of $15.1 \mathrm{~kg}$ and a variation from $12.5 \mathrm{~kg}$ to $18.4 \mathrm{~kg}$. In caiaué populations of Colombian origin, Rey et al. (2004) found BW between $5.0 \mathrm{~kg}$ and $11.0 \mathrm{~kg}$. Rios et al. (2015) reports variation in BW (average of at least 30 bunches per plant) between $5.5 \mathrm{~kg}$ and $18.9 \mathrm{~kg}$ for caiaué plants of Brazilian origin Manicoré, with controlled pollination of inflorescences using oil palm pollen. For oil palm, mean values for BW between $10.2 \mathrm{~kg}$ and $19.1 \mathrm{~kg}$ are reported in Dura variety of Angolan origin (REY et al., 2004), $10.0 \mathrm{~kg}$ to $24.0 \mathrm{~kg}$ in Dura variety and $10.0 \mathrm{~kg}$ to $13.5 \mathrm{~kg}$ in Tenera variety of Nigerian origin (OKWUAGWU et al., 2011). According to reports in the literature, when compared to oil palm, caiaué generally presents a lower BW and, in BC OGXG progenies, it is expected that the BW is closer to the oil palm average, which is the recurrent parent of the backcross. In the evaluated BC OGXG progeny, some individuals with low BW were found, however, around $16 \%$ of the individuals had a BW greater than $12.0 \mathrm{~kg}$, indicating that it is possible in the first generation of the backcross to select individuals with BW similar to that seen in the oil palm. 
Table 1. Descriptive statistics of the bunches components of 90 plants from a backcross progeny (caiaué $x$ oil palm) x oil palm.

\begin{tabular}{lrrrrr}
\hline \multirow{2}{*}{ Variable } & \multicolumn{5}{c}{ Descriptive statistics } \\
\cline { 2 - 6 } & Mean & Minimum & Maximum & \multicolumn{1}{c}{ DP } & CV (\%) \\
\hline BW & 9.0 & 2.7 & 21.3 & 3.4 & 37.5 \\
NFB & 46.0 & 21.9 & 65.5 & 10.6 & 23.0 \\
PFB & 11.6 & 0.5 & 42.8 & 9.3 & 80.1 \\
MNF & 72.7 & 46.7 & 92.0 & 9.7 & 13.4 \\
MPF & 86.5 & 29.9 & 98.5 & 20.5 & 23.7 \\
DIASP & 9.4 & 1.2 & 21.2 & 4.5 & 48.2 \\
OMNF & 37.6 & 15.0 & 57.8 & 8.7 & 23.1 \\
OMPF & 35.9 & 9.8 & 56.8 & 11.1 & 30.9 \\
OBNF & 12.6 & 2.6 & 25.7 & 4.5 & 36.1 \\
OBPF & 4.2 & 0.17 & 17.5 & 3.6 & 85.3 \\
POB & 16.0 & 5.81 & 34.8 & 5.4 & 34.0 \\
ODMNF & 62.4 & 47.15 & 79.8 & 7.3 & 11.7 \\
\hline
\end{tabular}

BW: fresh fruit bunches (FFB) weight in kilograms, NFB: percentage of normal fruits in FFB weight, PFB: percentage of parthenocarpic fruits in FFB weight, MNF: percentage of mesocarp in normal fruits, MPF: percentage of mesocarp in parthenocarpic fruits, DIASP: percentage of diaspore in fruit weight, OMNF: percentage of oil in humid mesocarp of normal fruits, OMPF: percentage of oil in humid mesocarp of parthenocarpic fruits, OBFN: percentage of oil from normal fruit in FFB weight, OBPF: percentage of oil from parthenocarpic fruit in FFB weight; POB: percentage of oil in FFB weight and ODMNF: percentage of oil in dry mesocarp of normal fruits.

Figure 2. Distribution of 90 individuals from an interspecific backcross progeny (caiaué $x$ oil palm) x oil palm in percentage value classes for different components of the bunches.
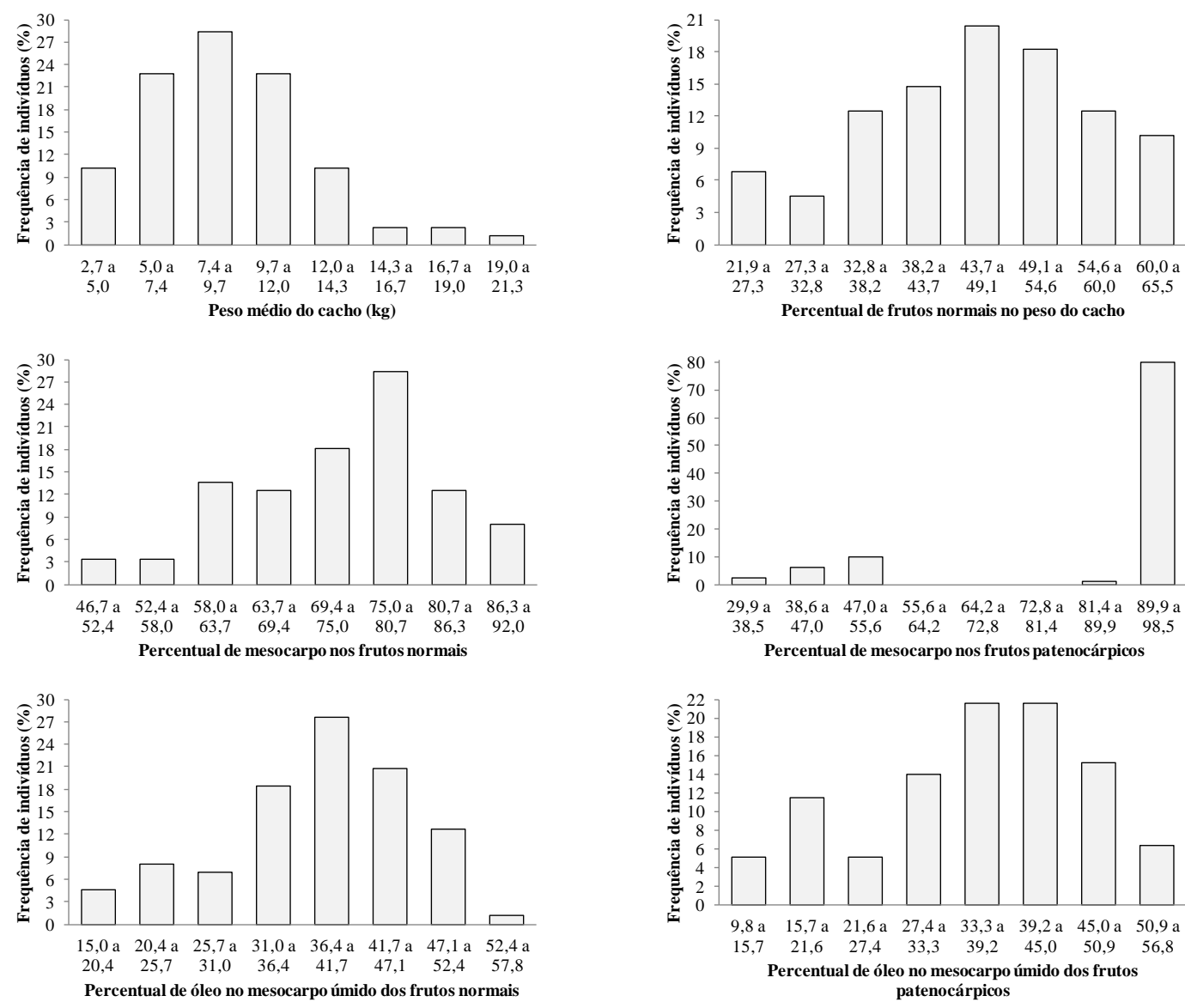

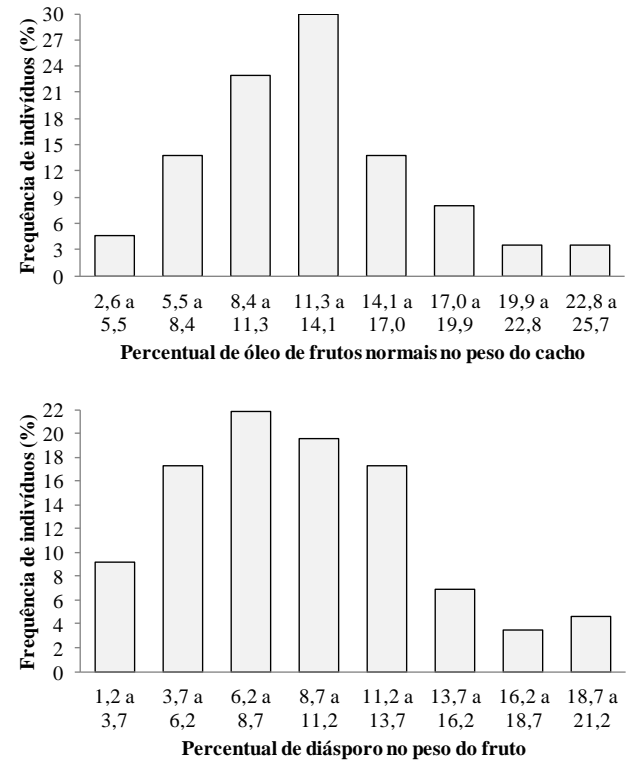

An important difference between oil palm and caiaue is the percentage of parthenocarpic fruits in the FFB weight (PFB), which is higher in caiaué. In caiaué families of Colombian origins, Rey et al. (2004) reported $52.0 \%$ to $58.0 \%$ PFB, for Brazilian origins, information compiled by Rios et al. (2015) indicate a variation from $0.0 \%$ to $45.7 \%$. For Tenera oil palm cultivars grown in the Brazilian Cerrado, the PFB ranged from $7.0 \%$ to 26.0\% (TELES et al., 2016). In the BC OGXG progeny, the PFB was $11.6 \%$ and varied from 0.5 to $42.8 \%$ (Table 1 ), with $74.0 \%$ of the individuals showing values below $16.0 \%$ and only $7.4 \%$ of the individuals presenting values greater than $20.0 \%$, indicating that in the first generation of interspecific backcrossing it is possible to select individuals with a low percentage of parthenocarpic fruits in the bunch.

The mean for the percentage of mesocarp in normal fruits weight (MNF) was $72.7 \%$ (range from $46.7 \%$ to $92.0 \%$ ), a lower value (test $T, p>$ 0.05) than the percentage of mesocarp in parthenocarpic fruits weight (MPF) which was $86.5 \%$ (range from $29.9 \%$ to $98.5 \%$ ). At the evaluation of BC OGXG progenies, Bastidas et al. (2007) found a mean value of $58.0 \%$ for MNF, with a variation from $53.0 \%$ to $63.8 \%$. Because there is a great variability in the percentage of mesocarp in the fruit among the Caiaue populations (REY et al., 2004; MURUGESAN; SHAREEF, 2014; RIOS et al., 2015), it is expected to observe variations in the interspecific crossing progenies according to the origins of the parents used in it. Despite showing a higher percentage of mesocarp, parthenocarpic fruits are smaller and
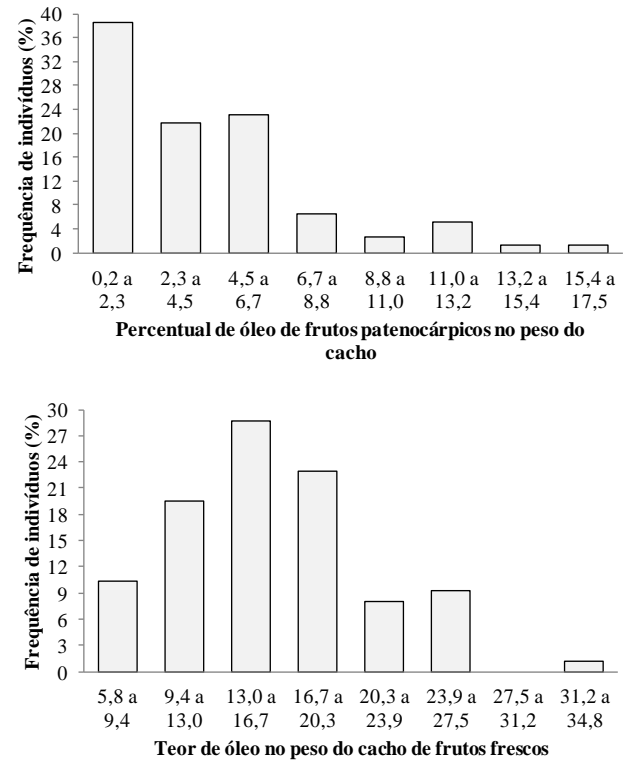

lighter than normal fruits when they do not abort before ripening, therefore, the least possible occurrence of this type of fruit in the bunch is desired. The average percentage of oil from normal fruits in FFB weight (OBNF) was $12.6 \%$ and in the parthenocarpic fruits (OBPF), it was only $4.2 \%$ (Table 1 ). The results show that when backcrossing is carried out using oil palm as a recurrent parent, the average percentage of parthenocarpic fruits is close to that seen in oil palm.

The diaspore of normal fruits is composed of the embryo, endocarp and endosperm, the latter used to extract palm kernel oil. The percentage of diaspore in fruit weight (DIASP) of the BC OGxG progeny was $9.4 \%$, varying from $1.2 \%$ to $21.2 \%$, and the variation coefficient was $48.2 \%$ (Table 1). The highest proportion of progeny individuals (75\%) showed DIASP between $3.7 \%$ to $13.7 \%$; however, $14.9 \%$ had values greater than $13.7 \%$ and $9.2 \%$ less than $3.7 \%$ (Figure 2). In the evaluation of $B C$ OGxG progenies, Bastidas et al. (2007) observed a mean of $10.5 \%$ for DIASP, with a variation from $8.1 \%$ to $12.2 \%$ between progenies. DIASP presents a large variation both in caiaué and oil palm populations. In caiaué populations of Colombian origin, Rey et al. (2004) reported $48.0 \%$ to $69.0 \%$ for DIASP, while for Brazilian caiaué populations, Rios et al. (2015) found values from $7.0 \%$ to $23.5 \%$. For oil palm, Okwuagwu et al. (2011) found a mean of $60.7 \%$ for DIASP in Dura variety genotypes and $36.0 \%$ in Tenera variety. For Tenera variety oil palm cultivars, Teles et al. (2016) observed palm oil content in the FFB ranging from $25.0 \%$ to 
$36.0 \%$ and palm kernel oil in the endosperm from $0.8 \%$ to $2.5 \%$. As palm kernel oil is a secondary product in the palm oil production chain, since it represents only around $10.0 \%$ of the production of this oil, the breeding programs have not considered the production of this oil in the selection of genotypes.

For the percentage of palm oil in the humid mesocarp, no statistically significant difference was found in the progeny BC OGXG ( $T$ test, $\mathrm{P}<0.05)$ between the mean obtained for OMNF (37.6\%) and OMPF (35.9\%). In a study carried out with caiaué plants from five different origins in the Brazilian Amazon, España et al. (2018) found a mean value of $28.6 \%$ for OMNF, with a variation from $19.8 \%$ to $33.6 \%$ between origins, values below the mean observed in the progeny BC OGXG. Despite their higher proportion of mesocarp in the fruit and a percentage of oil in the mesocarp similar to normal fruits, parthenocarpic fruits result in less oil production over the bunch weight. In addition to parthenocarpic fruits having a high percentage of abortion before maturation, they also have a problem in industrial processing. As parthenocarpic fruits do not have a diaspore as in normal fruits, the efficiency of industrial presses in oil extraction is lower, as this equipment are developed and adjusted to extract oil from the mesocarp of fruits with diaspores produced by normal fruits (FREITAS et al., 2021). In the processing, after fruits being separated from bunches in the threshing machine, these are transfer to the digester, whereby through the action of the rotating beater arms the fruit is pounded and obtained the digested mash (oil, moisture, fiber and diaspore). When there is high quantity of parthenocarpy fruits the efficiency of the digester is reduced. After digest the nuts are separated from the mash and the palm oil is extracted from the fibers by mechanical pressure in a pressing machine. When analyzing the percentage of oil in the FFB, the average value of the oil from normal fruits (OBNF) was $12.6 \%$, varying from $2.7 \%$ to $25.7 \%$, and from parthenocarpic fruits (OBPF), the average was $4.2 \%$, ranging from $0.2 \%$ to $17.5 \%$. The percentage of oil in the dry mesocarp was evaluated only for the mesocarp of normal fruits (ODMNF) and varied from $47.2 \%$ to $79.8 \%$, with a mean of $62.4 \%$. In the final stages of oil palm fruit maturation oil accumulation in the mesocarp is accompanied by loss of water, but without increase in non-oily solids content (FREITAS et al., 2021). The palm oil content in humid mesocarp of normal fruits was no statistically significant difference from the found in the paternocarpic fruits, therefore, the oil content in the dry mesocarp should also not be significantly different between these types of fruits.

A compilation of the literature reporting a variation in the percentage of palm oil in FFB (POB) from $18.3 \%$ to $25.5 \%$ in palm oil, $1.7 \%$ to $4.4 \%$ in caiaué and $3.8 \%$ to $17.0 \%$ in interspecific F1 hybrids (caiaué $x$ oil palm) (RIOS et al., 2015). $\mathrm{POB}$ is an important characteristic for the genetic improvement of oil palm, since palm oil is the product traded as commodity, although FFB production is the main component of palm oil productivity (OKWUAGWU et al., 2008; OKOYE et al., 2009). The POB found in the $B C$ OGxG progeny was $16.0 \%$ with a range from $5.8 \%$ to $34.8 \%$ and $\mathrm{CV}$ of $34,0 \%$ (Table 1), with a higher proportion of progeny individuals in the range of $9.4 \%$ to $20.3 \%$ (Figure 2 ), values that are similar to the range reported for ISH OxG by Rios et al. (2015). Approximately $10.0 \%$ of the progeny individuals showed values higher than those reported by Rios et al. (2015) for oil palm and all of them were higher than the values of caiaué, indicating that the genetic inheritance of oil palm predominated for this variable.

The correlations between the bunches components (Table 2) demonstrated that the percentage of palm oil in fruit mesocarp is the principal determinant of the percentage of oil in $F F B$ weight (POB), with greater importance for OMNF and OBNF than for OMPF and OBFP, as indicated by the high and positive correlations between OMNF x POB (0.72), OMPF x POB (0.63), OBNF $x$ POB (0.75) and OBPF $\times$ POB (0.56). Mean, positive and significant values were observed for the correlations between $\mathrm{BW} x \mathrm{POB}(0.23), \mathrm{FNC} x$ POB (0.27), PFB $x$ POB (0.32) and MNF $x$ POB (0.26). The frequencies of individuals in classes according to the mean for the bunch components (Figure 2), as well as the correlations observed between these components (Table 2), indicate that it is possible in $B C O G \times G$ progenies to select individuals with favorable physicochemical characteristics of the bunches for genetic improvement, with gains for $\mathrm{POB}$. 
Table 2. Correlations between bunches components of 90 plants from a backcross progeny (caiaué $x$ oil palm) $x$ oil palm.

\begin{tabular}{|c|c|c|c|c|c|c|c|c|c|c|c|}
\hline Variable & NFB & PFB & MFN & MPF & DIASP & OMNF & OMPF & OBNF & OBPF & POB & ODMNF \\
\hline BW & 0.17 & -0.07 & 0.05 & -0.06 & 0.02 & 0.17 & 0.17 & $0.28 * *$ & -0.05 & $0.23 *$ & -0.13 \\
\hline NFB & & $-0.45 * *$ & $-0.25^{*}$ & -0.21 & $0.32 * *$ & 0.10 & 0.08 & $0.63 * *$ & $-0.36 * *$ & $0.27^{*}$ & -0.02 \\
\hline PFB & & & 0.14 & $0.42 * *$ & $-0.27 *$ & 0.03 & 0.10 & $-0.22 *$ & $0.80 * *$ & $0.32 * *$ & -0.09 \\
\hline MNF & & & & -0.03 & $-0.61 * *$ & 0.01 & -0.15 & $0.28 * *$ & 0.02 & $0.26^{*}$ & -0.13 \\
\hline MPF & & & & & 0.01 & 0.03 & 0.10 & -0.13 & $0.34 * *$ & 0.15 & 0.00 \\
\hline DIASP & & & & & & -0.07 & 0.09 & -0.10 & -0.16 & -0.20 & 0.12 \\
\hline OMNF & & & & & & & $0.72 * *$ & $0.67 * *$ & $0.28 *$ & $0.72 * *$ & $0.25^{*}$ \\
\hline OMPF & & & & & & & & $0.42 * *$ & $0.49 * *$ & $0.63^{* *}$ & 0.20 \\
\hline OBNF & & & & & & & & & -0.10 & $0.75^{* *}$ & 0.04 \\
\hline OBPF & & & & & & & & & & $0.56 * *$ & 0.02 \\
\hline РОВ & & & & & & & & & & & 0.06 \\
\hline
\end{tabular}

BW: fresh fruit bunches (FFB) weight in kilograms, NFB: percentage of normal fruits in FFB weight, PFB: percentage of parthenocarpic fruits in FFB weight, MNF: percentage of mesocarp in normal fruits, MPF: percentage of mesocarp in parthenocarpic fruits, DIASP: percentage of diaspore in fruit weight, OMNF: percentage of oil in humid mesocarp of normal fruits, OMPF: percentage of oil in humid mesocarp of parthenocarpic fruits, OBFN: percentage of oil from normal fruit in FFB weight, OBPF: percentage of oil from parthenocarpic fruit in FFB weight; POB: percentage of oil in FFB weight and ODMNF: percentage of oil in dry mesocarp of normal fruits. ${ }^{* *}$ and*: significant at 1 and $5 \%$ of probability of the $t$ test.

Descriptive statistics (Table 3) and the distribution of means (Figure 3) for the percentage composition of fatty acids in palm oil indicate wide variation in the BC OGXG progenies. The largest variation among fatty acids was found for C18:0, with an amplitude of $1.4 \%$ to $8.4 \%$ and CV of $32 \%$ and $100 \%$ of individuals with a value higher than that observed for the ancestral caiaué, which contributes, on average, with $25 \%$ of the genome in the BC OGxG progeny. It is observed that some individuals ( 11\%) of the progeny present values for C18:0 above $6.1 \%$ (Figure 3), therefore, above the range established by Codex Alimentarius (FAO, 2017) for palm oil, between $3.5 \%$ and $6.0 \%$.

Table 3. Descriptive statistics of the percentage composition of fatty acids ${ }^{1}$ in palm oil produced by 90 plants from a backcross progeny (caiaué $x$ oil palm) $x$ oil palm and oil in the dry mesocarp of normal fruits (ODMNF).

\begin{tabular}{lcccccc}
\hline \multirow{2}{*}{ Fatty acid } & \multicolumn{7}{c}{ Statistics observed in the BC OGxG progeny } \\
\cline { 2 - 5 } & Mean $^{2}$ & $\begin{array}{c}\text { Standard } \\
\text { deviation }\end{array}$ & $\begin{array}{c}\text { Maximum } \\
\text { value }\end{array}$ & Minimum value & CV (\%) & *Caiaué \\
\hline C14:0 - Myristic & 0.28 & 0.09 & 0.54 & 0.13 & 33.66 & 0.50 \\
C16:0 - Palmitic & 30.67 & 3.32 & 37.75 & 23.88 & 10.83 & 27.22 \\
C18:0 - Stearic & 4.40 & 1.39 & 8.35 & 2.43 & 31.66 & 1.79 \\
C18:1 - Oleic & 52.45 & 3.85 & 62.26 & 44.52 & 7.35 & 46.60 \\
C18:2 - Linoleic & 10.75 & 2.02 & 16.83 & 6.43 & 18.76 & 20.39 \\
C18:3 - Linolenic & 0.40 & 0.07 & 0.63 & 0.26 & 18.38 & 1.58 \\
C20:0 - Arachidic & 0.42 & 0.08 & 0.60 & 0.26 & 19.42 & 0.18 \\
SFA & 35.77 & 3.66 & 43.20 & 27.60 & 10.00 & 29.69 \\
UFA & 63.60 & 3.60 & 72.00 & 55.9 & 5.70 & 68.57 \\
USR & 1.81 & 0.30 & 2.61 & 1.29 & 16.40 & 2.31 \\
ODMNF & 62.85 & 7.72 & 79.75 & 47.15 & 12.28 & 43.10 \\
\hline SFA:
\end{tabular}

SFA: saturated fatty acids, UFA: unsaturated fatty acids and USR: unsaturated/saturated fatty acids ratio. ${ }^{*}$ Female parent Elaeis oleifera $(\mathrm{O})$ of the interspecific hybrid plant (ISH OxG) used to generate the backcross (BC OGxG) characterized for the composition of the bunches. ${ }^{1}$ The identification of fatty acids was performed with the commercial fatty acid methyl esters (FAME) available which present all the fatty acids from the mesocarp oil. The retention times of C14:0, C16:0, C18:0, C18:1, C18:2, C18:3 and C20:0 was 3.84, 5.28, 7.32, 7.65, 8.23, 9.15, 10.09 minutes respectively.

${ }^{2}$ mean obtained from samples of two bunches with three replicates of each sample. 
Figure 3. Distribution of 90 individuals from an interspecific backcross progeny (caiaué $x$ oil palm) x oil palm in class of percentage values of fatty acids in the composition of palm oil. * Values regarding the female parent of the species caiaué (E. oleifera) used in the generation of the F1 hybrid.

C 14:0
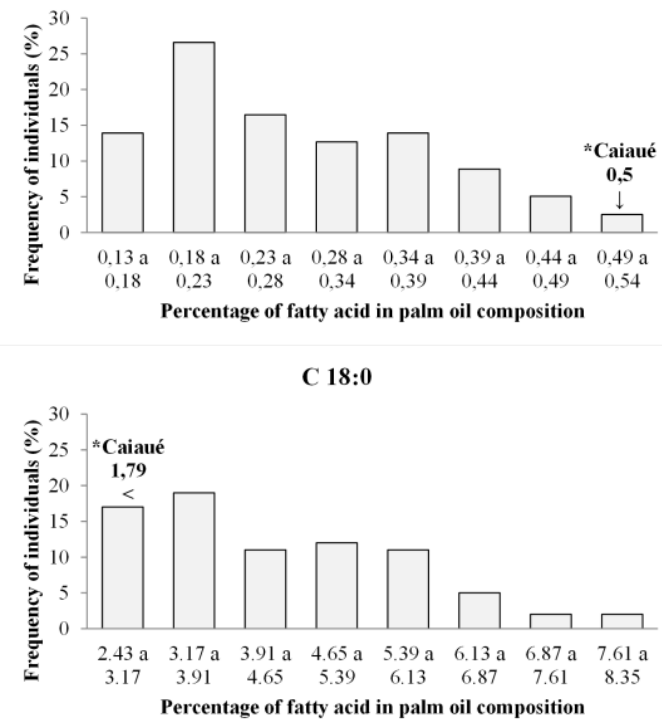

C 18:2

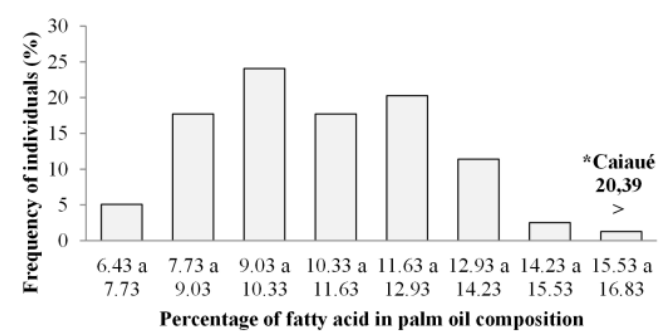

C 20:0

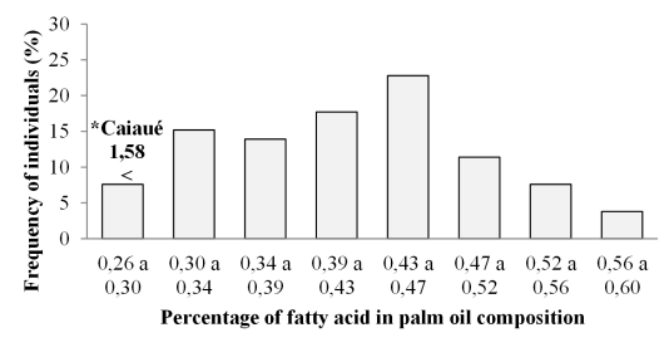

Unsaturated fatty acids

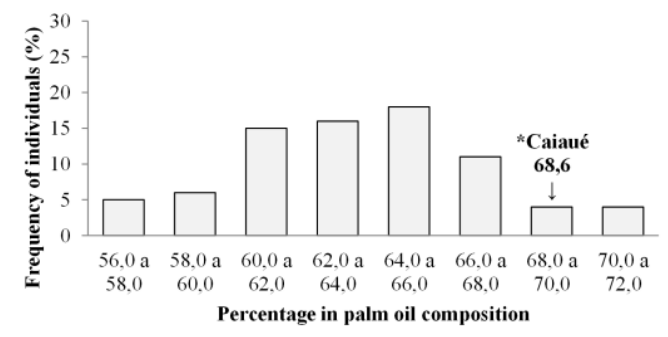

To represent the magnitude of the differences within the BC OGXG progeny and the selection possibilities, one can compare, for example, three individuals considering the
C 16:0

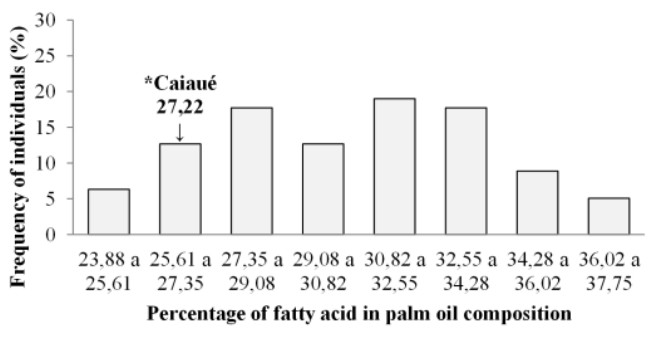

C 18:1

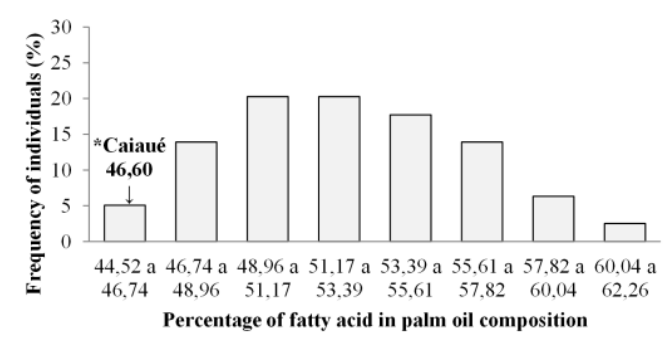

C 18:3

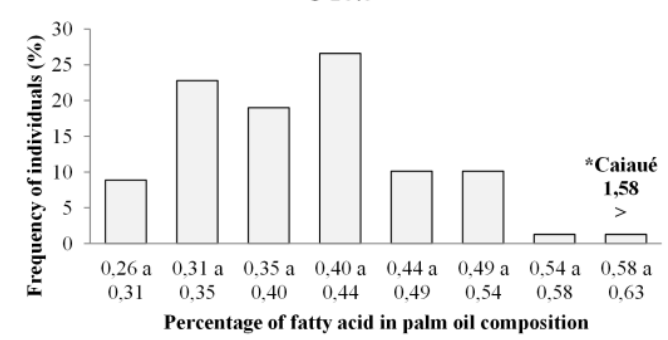

Saturated fatty acids

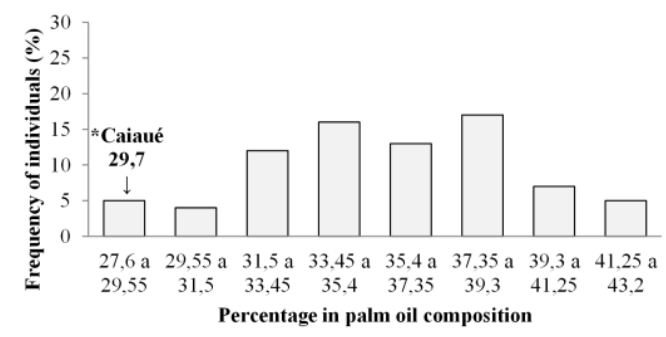

Unsaturated / Saturated fatty acids

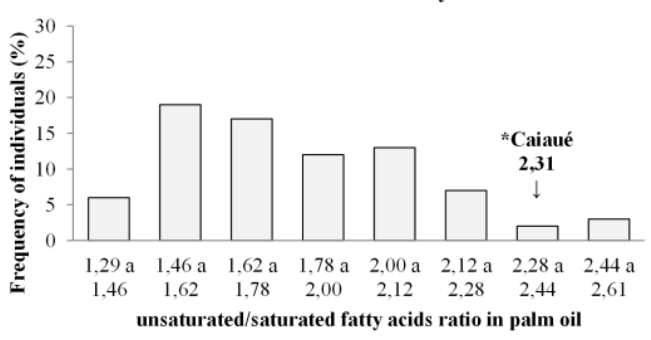

principal fatty acids in the composition of palm oil (Figure 4). 
Figure 4. Fatty acid composition of palm oil from three individuals from a backcross progeny (caiaué $x$ oil palm) x oil palm.

$\square \mathrm{C} 16: 0 \quad \mathrm{C} 18: 0 \quad \square \mathrm{C} 18: 1 \quad \square \mathrm{C} 18: 2$

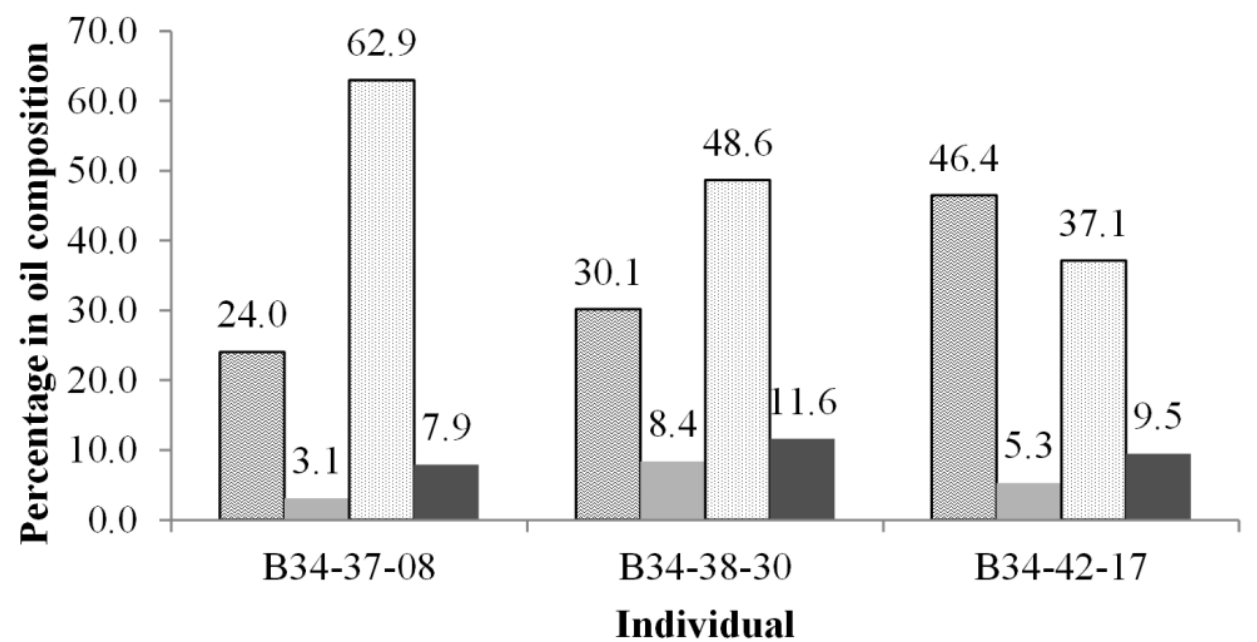

As shown by Sambanthamurthi et al. (2000), it is found in the typical composition of palm oil produced in Malaysia, the mean values of $43.5 \%$ (39.2\% to $45.8 \%$ ) of $\mathrm{C} 16: 0,39.8 \%$ (37.4\% to $44.1 \%)$ of $\mathrm{C} 18: 1 ; 10.2 \%(8.7 \%$ to $12.5 \%)$ of C18:2 and $4.3 \%(3.7 \%$ to $5.1 \%)$ of $\mathrm{C} 18: 0$. These four fatty acids together represent on average, $97.8 \%$ of the total fatty acids in palm oil. When analyzing the composition of the palm oil produced by five different Brazilian caiaué origins, Espana et al. (2018) reports values between $25.7 \%$ to $29.3 \%$ for $\mathrm{C} 16: 0 ; 45.9 \%$ to $53.3 \%$ for C18:1; from $13.4 \%$ to $18.3 \%$ for C18:2 and from $1.4 \%$ to $3.6 \%$ for $\mathrm{C} 18: 0$. In the BC OGXG progeny, the individual B34-42-17 presented $46.4 \%$ of C16: 0 and $5.3 \%$ of $\mathrm{C} 18: 0$ in the oil composition, which are high values for palm oil, while the B34-38-30 presents $30 \% \mathrm{C} 16: 0$ and $8.5 \% \mathrm{C} 18: 0$, therefore, compositions where stearins would present very different melting behavior, attending to different applications of fats in the food industry. The individual B34-37-08 presented $62.9 \%$ of $\mathrm{C} 18: 1$ in the composition of its oil, which is the highest value for this fatty acid among individuals of the progeny, and $8 \%$ of C18:2, where both unsaturated fatty acids represented $70.9 \%$ of the oil composition. On the other hand, it presented $24 \%$ of $\mathrm{C} 16: 0$, a value much lower than that usually found in oil produced by oil palm (39.2\% to $45.8 \%$ ) and also when considering the values found in caiaue oil ( $25.7 \%$ to $29.3 \%$ ). The high percentage of the principal unsaturated fatty

acids (C18:1 and C18:2), associated with the low percentage of the main saturated fatty acid (C16:0), in the oil of individual B34-37-08 indicates that most of the oil can remain in the liquid form at room temperature, similar to what occurs with caiaué oil.

The following fatty acids stood out in the average of the BC OGXG progeny: the unsaturated C18:1 (52.5\%) and C18:2 (10.8\%) and the saturated $\mathrm{C} 16: 0(30.7 \%)$ and $\mathrm{C} 18: 0$ (4.4\%) fatty acids. In total, these four fatty acids add up to $98.4 \%$ of the total fatty acids. In comparison with the ancestral caiaué, $94.9 \%$ of individuals from the BC OGXG progeny showed higher values for C18:1, 100\% lower values for C18:2 and 81\% higher values for C16:0. Montoya et al. (2013) characterized palm oil from individuals from a progeny $B C$ OGXG and also found as the principal components the saturated fatty acid C18:1 (45.0\%) and C18:2 (11.0\%) together representing $56 \%$ of the fatty acids in the oil, followed by $\mathrm{C} 16: 0$ (38.8\%). In the characterization of ISH OxG palm oil samples produced by two companies in the State of Pará (Brazil), Antoniassi et al. (2018) found values of $52.7 \%$ to $56.9 \%$ and from $11.2 \%$ to $12.7 \%$ for the unsaturated fatty acids C18:1 and $\mathrm{C} 18: 2$, respectively. The results are consistent with the types of the materials evaluated because using oil palm as a recurrent parent results in a reduction in the percentage of unsaturated fatty acids in the backcross mean, although, as it was found, individuals may present really differentiated oil compositions. However, the 
values observed for $\mathrm{C} 16: 0$ (24.9\% to $29.5 \%)$ in the ISH OxG palm oil by Antoniassi et al. (2018) were lower than those observed on average in the progenies of the BC OGXG evaluated by Montoya et al. (2013), 38.8\%, and the value of $30.7 \%$ found in this study, therefore demonstrating that, on average, oil in the BC OGXG progenies have a higher proportion of saturated fatty acids than the oil produced by caiaué and also by the first generation of interspecific crossing (ISH OxG).

The percentage of saturated fatty acids (SFA) in the palm oil of the BC OGxG progeny (35.8\%) was higher than that found in the ancestral caiaue $(29.7 \%)$, whereas the percentage of unsaturated fatty acids (UFA) (63.6\%) was lower (68.6\%). As a result of these values, the UFA/SFA ratio (USR) in the palm oil of the BC OGXG progeny (1.81) was lower than that observed in the ancestral caiaue (2.31). In the BC OGXG progeny, on average, $25.0 \%$ of the caiaué genome is maintained, thus, the observed values tend to distance themselves from this parent and approach the recurrent parent, the oil palm. However, as there is a variation in the proportion of the caiaue genome in the backcross progeny, some individuals may be genetically closer to this species than the average progeny, which may explain, for example, individuals of the progeny ( $6.0 \%)$ that presented a percentage of AGI similar to the value observed in caiaué.

The fatty acid C18:1 (oleic), the main fatty acid in the composition of BC OGxG palm oil, showed a negative and significant correlation (Table 4) with the SFA C14:0 (-0.45), C16:0 (-0.75), C18:0 (-0.39) and the UFA C18:2 (-0.39). Yet, with the FA C18:3 (-0.01) and C20:0 (-0.17) the correlation, although negative, was low and not significant. The negative correlation between FA C18:1 and C18:2 was also reported by Montoya et al. (2013), that explain this negative correlation due to the fact that FA C18:1 is a substrate for the production of $\mathrm{C} 18: 2$, which occurs due to the action of the enzyme FAD2. High and positive correlations were identified between FA C14:0 and C16:0 (0.69), C18:2 and C18:3 (0.57) and C18:0 and C20:0 (0.72). The variation in the composition of the oil in fatty acids did not show a significant correlation with the percentage of oil in dry mesocarp (ODM), which indicates that the selection for a high percentage of ODM does not affect the composition of the oil and, on the other hand, the selection for gains in oil composition will not affect the gains for ODM.

Table 4. Correlations between the percentage of fatty acids in the palm oil of 90 plants from a backcross progeny (Caiaué $x$ palm oil) $x$ palm oil.

\begin{tabular}{llllllll}
\hline Fatty acid & C16:0 & C18:0 & C18:1 & C18:2 & C18:3 & C20:0 & ODM \\
\hline C14:0 & $\mathbf{0 . 6 9 * *}$ & -0.21 & $-0.45^{* *}$ & -0.11 & $-0.25^{*}$ & $-\mathbf{0 . 3 9 * *}$ & 0.00 \\
C16:0 & & -0.01 & $-0.75^{* *}$ & -0.19 & $-0.28^{*}$ & -0.18 & -0.06 \\
C18:0 & & & $-0.39 * *$ & 0.07 & -0.19 & $\mathbf{0 . 7 2 * *}$ & -0.03 \\
C18:1 & & & & $-0.39 * *$ & -0.01 & -0.17 & 0.00 \\
C18:2 & & & & & $0.57^{* *}$ & 0.10 & 0.09 \\
C18:3 & & & & & & 0.02 & 0.01 \\
C20:0 & & & & & & & -0.13 \\
\hline
\end{tabular}

ODM: percentage of the oil in the dry mesocarp. ${ }^{* *}$ and ${ }^{*}$ : significant at 1 and $5 \%$ of probability by the t test.

The interspecific hybridization between caiaué and oil palm has as main objective the introduction of genetic resistance to Bud Rot desease in the oil palm, which has already been demonstrated in the F1 hybrids (GOMES JR et al., 2019). The genetic control of resistance to $B R$ is unknown and there is no information about segregation of this characteristic in backcross generations. However, the backcross of the interspecific F1 hybrid with the oil palm was recommended as a solution to the fertility problems verified in the interspecific F1 hybrids
(BARBA, 2016). The results of this study indicate that the use of caiaue in the oil palm genetic improvement will allow also the development of cultivars with different oil compositions, with specific profiles to attend differents purpose of use. However, the commercial use of firstgeneration backcross genotypes will depend of cloning, since these cannot be reproduced by seeds due to segregation. Once cloned, genotypes can be evaluated for other characteristics, such as resistance to Bud Rot and bunches productivity. 


\section{Conclusions}

The large phenotypic variation is observed in interspecific backcross (caiaué $x$ oil palm) $x$ oil palm, both for the physicochemical characterization of the bunches and in the composition of palm oil in fatty acids.

Unsaturated fatty acids predominate in composition of interspecific backcross (caiaué $x$ oil palm) $x$ oil palm, with predominance of oleic fatty acid.

The simultaneous selection of individuals from progenies of the $B C O G \times G$ is possible for high yield of palm oil in the fresh fruits bunch and increasing or reducing the percentage of saturated or unsaturated fatty acids in the oil composition.

\section{Acknowledgments}

The authors acknowledge financial support by CNPq Projects 483317 / 2012 - 8.

\section{References}

ANTONIASSI, R.; MACHADO, A. F. DE F.; WILHELM, A. E.; GUEDES, A. M. M.; BIZZO, H. R.; OLIVEIRA, M. E. C.; YOKOYAMA, R.; LOPES, R. Óleo de palma de alto oleico produzido no Brasil no ano de 2016. Embrapa Agroindústria de Alimentos, Rio de Janeiro, 2018. 6 p. (Comunicado Técnico, 229). Disponível em: https://ainfo.cnptia.embrapa.br/digital/bitstream /item/193393/1/CT-229-oleo-palma-altooleico.pdf. Acesso em: 15 maio 2020.

AOAC. Official method of Analysis. 18. ed. Washington DC: Association of Official Analytical Chemists, 2005.

BARBA, J. Introgresión de genes $E$. guineensis en híbridos interespecíficos OxG para recuperar la fertilidad del polen y otras características deseables en palma de aceite. Revista Palmas, v.37, n.esp., Tomo I, p.285-293, 2016. Avaliable from:

https://publicaciones.fedepalma.org/index.php/p almas/article/view/11912. Accessed: 25 may 2021.

BASTIDAS, S.; PEÑA, E.; REYES, R.; PÉREZ, J.; TOLOSA, W. Agronomic behavior of the $B C 1$ hybrid cultivar of oil palm (Elaeis oleifera $\times$ Elaeis guineensis) $\times$ Elaeis guineensis. Revista Corpoica Ciencia y Tecnologia Agropecuarias, v.8, n.1, p.511 , 2007. https://doi.org/10.21930/rcta.vol8 num1 art:77.
CADENA, T., PRADA, F., PEREA, A.; ROMERO, H. Lipase activity, mesocarp oil content, and iodine value in oil palm fruits of Elaeis guineensis, Elaeis oleifera, and the interspecific hybrid OxG (E. oleifera $\times$ E. guineensis). Journal of the Science of Food and Agriculture, v. 93, n. 3, p. 674-80, 2012. https://dx.doi.org/10.1002/jsfa.5940.

CHAVES, G., LIGARRETO-MORENO, G.A.; CAYONSALINAS, D.G. Physicochemical characterization of bunches from American oil palm (Elaeis oleifera HBK Cortes) and their hybrids with African oil palm (Elaeis guineensis Jacq.). Acta Agronómica, v.67, n.1, p.168-176, 2018. https://dx.doi.org/10.15446/acag.v67n1.62028.

CORLEY, R. H. V.; TINKER, P. B. The oil palm. Oxford: Blackwell Science, 2016. 692p. https://doi.org/10.1002/9781118953297.

ESPAÑA, M.; MENDONÇA, S.; CARMONA, P.; GUIMARAES, M.; CUNHA, R.N.V; SOUZA JUNIOR, $M$. Chemical Characterization of the American Oil Palm from the Brazilian Amazon Forest. Crop Science, v.58, n.5, p.1982-1990, 2018. https://dx.doi.org/10.2135/cropsci2018.04.0231.

FAO. Codex Alimentarius. Codex Stan 210. Codex Standard for named vegetable oils. Adopted 1999. Revision 2017. Avaliable from: http://www.fao.org/fao-who-

codexalimentarius/standards/list-standards/en/. Accessed: 25 may 2021.

FREITAS, A.F.; LOPES, R.; CUNHA, R.N.V.; PINA, A.J.A.; RESENDE, M.D.V.; GOMES JÚNIOR, R.A. Genotypic values and genetic correlations for components and oil content of bunch of hybrids between caiaué and dendê. Colloquium Agrariae, v.17, n.1, p.79-92, 2021. DOI: https://dx.doi.org/10.5747/ca.2021.v17.n1.a422.

GOMES JR., R.A.; LOPES, R.; CUNHA, R.N.V.; PINA, A.J.A.; QUARESMA, C.E.; CAMPELO, R.D.; RESENDE, M.D.V. Selection gains for bunch production in interspecific hybrids between caiaué and oil palm. Pesquisa Agropecuária Brasileira, v.54, p.e00819, 2019. https://doi.org/10.1590/S16783921.pab2019.v54.00819.

HARTMAN, L.; LAGO, R.C.A. Rapid preparation of fatty acid methyl ester from lipids. Laboratory 
Practice, v.22, n.6, p.475-476, 1973. PMID: 4727126.

LIEB, V.M.; KERFERS, M.R.; KRONMÜLLER, A.; ESQUIVEL, P.; ALVARADO, A.; JIMÉNEZ, V.M.; SCHMARR, H-G.; CARLE, R.; SCHWEIGGERT, R.M.; STEINGASS, C.B. Characterization of Mesocarp and kernel lipids from Elaeis guineensis Jacq., Elaeis oleifera [Kunth] Cortés, and their interspecific hybrids. Journal of Agricultural and Food Chemistry, n.65, p.3617-3626, 2017. https://dx.doi.org/10.1021/acs.jafc.7b00604.

LUCCI, P.; PACETTI, D.; FREGA, N.G.; MOZZON, M. Phytonutrient concentration and unsaturation of glycerides predict optimal harvesttime for Elaeis oleifera $\times E$. guineensis palm oil hybrids. European Journal of Lipid Science and Technology, v.117, n.7, p.1027-1036, 2015. https://doi.org/10.1039/C5FO01083G

LUCCI, P.; BORRERO, M.; RUIZ, A.; PACETTI, D.; FREGA, N. G.; DIEZ, O.; OJEDA, M.; GAGLIARDI, R.; PARRA, L.; ANGEL, M. Palm oil and cardiovascular disease: a randomized trial of the effects of hybrid palm oil supplementation on human plasma lipid patterns. Food Function, n.7, p.347354, 2016. https://dx.doi.org/10.1039/c5fo01083g.

MONTOYA, C.; LOPES, R.; FLORI, A.; CROS, D.; CUELLAR, T.; SUMMO, M.; ESPEOUT, S.; RIVALLAN, R.; RISTERUCCI, A.; BITTENCOURT, D.; ZAMBRANO, J.R.; ALABCÓN, G.; WILMAR, H.; VILLENEUVE, P.; PINA, M.; NOUY, B.; AMBLARD, P.; RITTER, E.; LEROY, T.; BILLOTTE, N. Quantitative trait loci (QTLs) analysis of palm oil fatty acid composition in an interspecific pseudo-backcross from Elaeis oleifera (H.B.K.) Cortés and oil palm (Elaeis guineensis Jacq.). Tree Genetics \& Genomes, v.1, p.1, 2013. https://dx.doi.org/10.1007/s11295-013-0629-5.

MOZZON, M.; FOLIGNI, R.; TYLEWICZ, U. Chemical characteristics and nutritional properties of hybrid palm oils. In: Waisundara, V. (Org.). Palm Oil. 1 ed. London: IntechOpen, v.1, p.149-170, 2018. https://doi.org/10.5772/intechopen.75421

MURUGESAN, P.; SHAREEF, M. Yield, bunch quality and vegetative traits of American oil palm (Elaeis oleifera, HBK) population in India. Indian Journal of Horticulture, n.71, p.23-27, 2014. Available

from: https://www.indianjournals.com/ijor.aspx?target =ijor:ijh\&volume=71\&issue=1\&article=005.

Accessed: 25 may 2021.

NTSOMBOH-NTSEFONG, G.; NGANDO-EBONGUE, G.F.; AJAMBANG-NCHU, W.; MAHO-YALEN, J.E.; TABI-MBI, K.; VINCENT, A.; BELL, J.M.; YOUMBI, E. Chapter 10 - Oil Palm. In: Gupta, S.K. (Org.). Breeding Oilseed Crops for Sustainable Production. Academic Press, 2016. p.217-273. https://doi.org/10.1016/B978-0-12-8013090.00010-0.

OKOYE, M.N.; OKWUAGWU, C.O.; UGURU, M.I. Population improvement for fresh fruit bunch yield and yield components in oil palm (Elaeis guineensis Jacq.). American-Eurasian Journal of Scientific Research, v.4, p.59-63, 2009. Available from: https://www.idosi.org/aejsr/4(2)09/2.pdf. Accessed: 25 may 2021.

OKWUAGWU, C.O.; ATAGA, C.D.; OKOYE, M.N.; OKOLO, E.C. Germplasm collection of highland palms of Afikpo in Eastern Nigeria. Bayero Journal of Pure and Applied Sciences, v.4, n.1, p.112-114, 2011. http://dx.doi.org/10.4314/bajopas.v4i1.25

OKWUAGWU, C.O.; OKOYE, M.N.; OKOLO, E.C.; ATAGA, C.D.; UGURU, M.I. Genetic variability of fresh fruit bunch yield in Deli/dura $\times$ tenera breeding populations of oil palm (Elaeis guineensis Jacq.) in Nigeria. Journal of Tropical Agriculture, v.46, p.52-57, 2008. Available from: http://jtropag.kau.in/index.php/ojs2/article/view /188/188. Accessed: 25 may 2021.

RAO, V.; SOH, A. C.; CORLEY, R. H. V.; LEE, C. H.; RAJANAIDU, N.; TAN, Y. P.; CHIN, C. W.; LIM, K. C.; TAN. S. T.; LEE, T. P.; NGUI, M. A critical reexamination of the method of bunch quality analysis in oil palm breeding. Palm Oil Research Institute of Malaysia, Occasional paper, n.9, 1983. Available from: http://isopb.mpob.gov.my/pdffile/5th/P2_Paper \%20ISA\%20et\%20al\%20for\%20ISOPB\%202011.pd f. Accessed: 25 may 2021.

REY, L; GÓMES, P.L.; AYALA, I.; DESGADO, W.; ROCHA, P. Colecciones genéticas de palma de aceite Elaeis guineensis (Jacq.) y Elaeis oleifera (H.B.K.) de Cenipalma: Características de importância para el sector palmicultor. Revista Palmas, n.25 (esp.), p.39-48, 2004. Available 
from:

https://publicaciones.fedepalma.org/index.php/p almas/article/view/1065. Accessed: 25 may 2021.

RIOS, S.A.; CUNHA, R.N.V.; LOPES, R.; BABCELOS, E.; LIMA, W.A.A.; RODRIGUES, M.R.L.; KRUG, C.; BITTENCOURT, D.M.; QUISEN, R.Q.; GOMES JUNIOR, R.A.; ROCHA, R.N.C. Caiaué. In: LOPES, R.; OLIVEIRA, M.S.P.; CAVALLARI, M.M.; BARBIERI, R.L.; CONCEIÇÃO, L.D.H.C. (Org.). Palmeiras Nativas do Brasil. 1. ed. Brasília, DF: Empresa Brasileira de Pesquisa Agropecuária, 2015. v.1, p.211-246.

RODRIGUEZ, J.C.; GÓMEZ, D.; PACETTI, D.; NÚÑEZ, O.; GAGLIARDI, R.; FREGA, N.G.; OJEDA, M.L.; LOIZZO, M.R.; TUNDIS, R.; LUCCI, P. Effects of the fruit ripening stage on antioxidant capacity, total phenolics, and polyphenolic composition of crude pal'm oil from interspecific hybrid Elaeis oleifera $\mathrm{x}$ Elaeis guineensis. Journal Agricultural Food Chemistry, n.64, p.852-859, 2016. http://dx.doi.org/10.1021/acs.jafc.5b04990.

SAMBANTHAMURTHI, R.; SUNDRAM, K.; TAN, Y. Chemistry and biochemistry of palm oil. Progress in Lipid Research, n.39, p.507-558, 2000. http://dx.doi.org/10.1016/s0163-7827(00)00015$\underline{1 .}$

SOCHA, J.; CAYON, D.; LIGARRETO, G.; CHAVES, G. Effect of pollen doses on fruit formation and oil production in two hybrid palm genotypes (Elaeis oleifera H.B.K. Cortes x Elaeis guineensis Jacq.). Agronomia Colombiana, Bogotá, v.37, n.1, p.1217, 2019. http://dx.doi.org/10.15446/agron.colomb.v37n1. $\underline{75313}$.

TELES, D.A.A.; BRAGA, M. F.; ANTONIASSI, R.; JUNQUEIRA, N. T. V.; PEIXOTO, J. R.; MALAQUIAS, J. V. Yield Analysis of Oil Palm Cultivated Under Irrigation in the Brazilian Savanna. Journal of the American Oil Chemists Society, v.93, n.2, p.193199, 2016. http://dx.doi.org/10.1007/s11746015-2765-6.

USDA. Oil Crops Data: Yearbook 2021 - Table 42 World vegetable oils supply and distribution. Available from: https://www.ers.usda.gov/dataproducts/oil-crops-yearbook/. Accessed: 25 may 2021. 